テレコバルト $r$ 線, ライナック $\mathrm{X}$ 線, 電子線による深 部線量率曲線について虫，すでに多くの報告がある。我 々は，テレコバルト $\gamma$ 線，ライナック $10 \mathrm{MVX}$ 線， 8， $10,12 \mathrm{MeV}$ 電子線の深部線量率曲線を Shallow chamber で測定した．ファントムとして，アクリライト板 を使用し，特にライナックの場合は，線量率が ${ }^{60} \mathrm{Co}-\gamma$ 線 のように一定でないから，絞り機構の下に透過型線量計 を挿大し，2ペンレコーダで記録させ測定を容易にし た。そして, Shallow chamber を用いて測定した深部線 量率曲線より, 照射野の違いによる表面線量, Build up の位膡，電子線の公称エネルギーと実用エネルギーの違 い，及び電子線の制動放射線の量を測定した。

\section{0. 術後乳癌放射線治療に於ける照射法の検討}

久留米大学医学部附属病院放射線治療センター

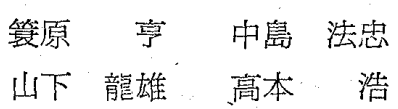

現在当放射線治療センターでは術後乳癌コバルト治療 を腋窩，鎖骨上窩，胸壁部の3 所に分けて行われてい るが腋筬と鎖骨上曧を一緒に照射し，胸壁部は現在のま ま（健側方向より60度患側へ胸鎖関節の下方 $2 \mathrm{~cm}$ 亿照 射野 $6 \times 12 \mathrm{~cm}$ の上縁）で照射するととを検討してい る。こ水は腋窝之鎖骨上筥を含も $16 \mathrm{~cm} \times 16 \mathrm{~cm}$ のかな り広い照射野で，胸鎖関節に照射野の左又は右端中心を とり，上腕骨骨頭部と上脑野を鉛ブロックで遮警し胸壁 部を切線照射する時，腋窝部への影響を考慮に入れ二重 照射を避けなければならない。この照射器具を使用すれ ば，健康組織の障憲を最小限にとどめ，つなぎ照射によ る重複をなくすととができる。

(座長集約)

この演題群は，放射線治療に执いて正磪な線量を照射 するための基礎的事項及び照射法の実際について検討し たあのである，以下それぞれについて述べる。

演題 6 放射線治療の外部照射における, 変形照射野 の線量計算についての報告である，照射野の中心軸にお ける線量と，照射野の辽縁における線量は散乱線附加の 差等により異る.今後さらに変形照射野面積と線量の関 係式の導入等について檢傠されるてとをのぞみたい。

演題 7 Linac 15 M I B 型の性能検討についての厗 告である。モニター線量計チェックはその誤差が士 $2 \%$ 程度であるので，1週間に1回のチェックで良いと言う 方針であるが，放射線治療に拈ける照射線量が数 1,000 $\mathrm{rad}$ と多いことから，モ二タ一線量計の土 $2 \%$ 蕠差を 簡単に䇤視することはできない，又X線，電子線の安定 した出力が得られるとしても，筡日の治䇣開始前の始業
点検において，モニタ一線量計の校正，照射野平坦度の チェックは必要だと思う。

演題 8 乳癌術後胸壁 ${ }^{60} \mathrm{Co}-\boldsymbol{r}$-ray 照射にお打る一方向 二閒照射法についての報告である.一う向照射によって， 線束方向，体位の再現性が良く，膀胸骨りンパ節及び前 胸壁の線量分布が均等 $(80 \%)$ になるとしている。一方 向二門照射で重複する照射野の線量補正，又入射側の皮 虔障害等の物理的，生物学的な問題について，対向二闍 照射法と比較してその有意性につねてあ触れるべきであ ろう。

演題 9 テレコバルト $\gamma$-ray，Linac X-ray，電子線の 深部線睲百分率曲線 Shallow chamber した報告である。報告では深部線量率曲線ししているが， これはある深さにおける時間当りの線量を示すと解釈す るとともでき，今回の報告内容に適した表現ではない。 従ってこの場合は深部量百分率曲線と表現した方が良い 之思う。

演題10 乳癌術後 ${ }^{60} \mathrm{C}-\gamma$-ray 照射において, 照射部位 固定具を作製し，又上肺野及び上腕骨頭部を遮へいする シャドウトレイを用いて，腋简及び鎖骨下リンパ節の同 時照射法についての報告である。

線管理座長 比嘉康孟 (沖繩県庁環境保健部)

\section{1. 透視下におけるカテーテル検查時の被曝線量 㪕隇化について}

九州厚生年金病院

○岡田寅彦岡部健吾 寒竹 誠治

〔目的〕

当院では，透視下による血管カテーテル検查が年々増 加の傾向にあり，それに伴う貟者，特に術者及び拹力者

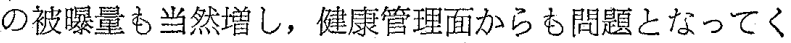
る。そこで我々は，カテーテル台上の操作に支障なく， X線管一I. I 間を，円形絞り一防護真で結び，被曝線量 軽減化を試み，好結果を得たので報告する。

[結果]

腹部透視において，防護具のみでは，息者の被曝線量 はわずかながらふえるが，円形絞りを併用するととに よって約30\%減らせた。，又，術者側（患者の側面方向） においては1/30と大幅に軴減できた。

尚，患者の生殖線量は約30\%減となったが，目的を達 成できず今後の課題としたい.

12. RI 検查時における被検者からの放射線量について 国立病院九州がんセンタ一田島 聖正 九州大学医学部附属病院放射線部

市村 睦子：中野秀一郎 